\title{
Pengembangan Sistem Pengisian Baterai Dengan Kombinasi Sumber Listrik Dari PLN dan Energi Surya
}

\author{
Muhammad Ridhwan Sufandi ${ }^{1)}$, Wiwit Indah Rahayu ${ }^{2)}$ \\ ${ }^{1,2)}$ Magister Teknik Elektro, Fakultas Teknik Universitas Tanjungpura Pontianak, \\ ${ }^{1)}$ RTS Kalimantan Barat, PT. Huawei Tech Invesment \\ ${ }^{2)}$ Staf Pengajar AMIK BSI Pontianak \\ e-mail : mr.sufandi86@gmail.com,wiwitindahrahayu@gmail.com
}

\begin{abstract}
Untuk memenuhi kebutuhan energi listrik di Base Transceiver Station (BTS) operator Hutchison Three Indonesia (H3I), maka dalam tesis ini saya fokuskan pada pengembangan sistem pengisian baterai dengan kombinasi sumber listrik dari PLN dan energi surya. Sering terjadinya pemadaman listrik bergilir, mengakibatkan waktu pengisian menjadi lebih lama sehingga diperlukan suplai energi cadangan. Salah satunya melalui pengembangan energi alternatif yaitu pengembangan energi surya di site 140392_Teluk Pasir Kabupaten Sekadau. Diharapkan pengembangan sistem kombinasi sumber listrik dari Perusahaan Listrik Negara (PLN) dan energi surya dapat mempersingkat waktu yang dibutuhkan untuk mempersingkat waktu pengisian baterai. Daya sistem pengendali kombinasi sumber ini akan menghasilkan daya output DC sebesar 80\%-90\%. Waktu yang dibutuhkan tanpa menggunakan sistem kombinasi sumber listrik adalah selama 29 jam 49 menit. Dengan adanya pemasangan 10 unit panel surya daya yang dihasilkan sebesar 2,4 KW dengan tegangan kerja sekitar 54,5V, pada kondisi kedua sumber energi menyala akan membutuhkan waktu pengisain baterai selama 14 jam 53 menit dengan kapasitas baterai sebesar 333,34 Ah (tegangan $48 \mathrm{~V}$ dan daya $16 \mathrm{KW}$ ) terjadi peningkatan kecepatan pengisian baterai sebesar $\pm 200 \%$.
\end{abstract}

Keywords- Pengisian Baterai, Alternatif Sumber BTS, Kombinasi Sumber Listrik

\section{Pendahuluan}

Kenyataannya sumber listrik dari PLN tidak mampu menyuplai listrik dengan maksimal, listrik sering padam dan tegangan listrik tidak stabil dapat menyebabkan peralatan elektronik rumah tangga rusak hal ini juga menyebabkan sistem kinerja semua pelayanan publik yang ada menjadi kurang maksimal, salah satunya kinerja dan kualitas layanan telekomunikasi di daerah Kabupaten Sekadau yang belum maksimal, terutama pada pengisian baterai yang lambat di Base Transceiver Station (BTS) operator Hutchison Three Indonesia (H3I) di daerah Teluk Pasir Kabupaten Sekadau. Maka dari itu diperlukannya sumber energi alternatif untuk membantu sumber listrik dari PLN, dengan menggabungkan sumber energi dari

PLN dengan energi cahaya matahari (Photovoltaic system) diharapkan akan dapat membantu mempercepat dan mempersingkat waktu yang dibutuhkan dalam pengisian baterai BTS.

\section{Teori Dasar}

\subsection{Pengertian Hibrid ${ }^{[1,2]}$}

Sistem tenaga listrik yang mempunyai dua pembangkit atau lebih dengan jenis pembangkit yang berbeda maka disebut Pembangkit Listrik Tenaga Hibrid. Biasa nya hybrid ini kombinasi antara angin dan surya, angain dan air, surya dan air, surya dan genset dan sebagainya.

\subsection{Energi Listrik ${ }^{[3]}$}

Jumlah muatan yang mengalir adalah kuat arus listrik dikalikan dengan lamanya arus tersebut mengalir, atau $\Delta \mathrm{Q}$ $=\mathrm{I} \Delta \mathrm{t}$.

Adapun besar energi yang diperlukan untuk memindahkan muatan pada hambatan tersebut dinyatakan dengan persamaan :

$W=V . \Delta Q$ dengan $\Delta Q=I . \Delta t$

Sehingga, untuk energi listrik memenuhi persamaan

$W=V \Delta t$

Keterangan :

$\mathrm{W}$ = Energi yang dihasilkan oleh sumber tegangan (Joule)

$\mathrm{V} \quad=$ Beda potensial listrik (Volt)

$\mathrm{I} \quad=$ Arus listrik dari sumber (Ampere)

$\Delta \mathrm{t}=$ Waktu (seconds)

Dengan menerapkan hukum ohm pada sebuah rangkaian listrik yaitu $\mathrm{V}=\mathrm{I}$.R, maka energi listrik dapat dituliskan dalam bentuk persamaan :

$W=V . I . \Delta t$

$W=. I^{2} \cdot R \cdot \Delta t$

$\left.W=. V^{2} / R\right) \cdot \Delta t$

Keterangan :

$\mathrm{R}=$ Hambatan (ohm)

2.3. Modul Surya/ Array ${ }^{[2,4,5,6,7,10]}$

2.3.1 Peletakan Modul Surya ${ }^{[2,4,5]}$

Sudut optimum peletakan sel surya, bertujuan untuk mendapatkan intensitas cahaya matahari yang tiba pada permukaan panel sehingga menghasilkan daya yang maksimum adalah pada sudut $15^{\circ}$. 


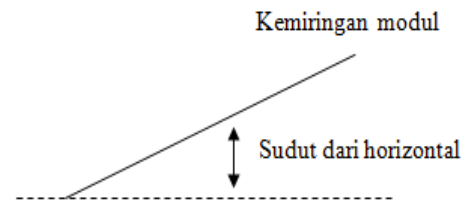

Gambar 1. Kemiringan modul ${ }^{[4]}$

2.3.2 Rangkaian Pemasangan Modul Surya ${ }^{[2,4,5,7,10]}$ a) Modul Seri

Dalam pemasangan modul pada sistem PV array, pada umumnya modul dapat dipasang seri sebanyak 3 atau 2 modul dalam satu string. Dimana jika modul terpasang seri maka tegangan modul akan naik, namun arusnya tetap. Namun jika dalam satu string terdapat 3 modul yang terpasang seri, maka outputnya adalah:

$\mathrm{V}=\mathrm{V}_{1}+\mathrm{V}_{2}+\mathrm{V}_{3}$ (Volt)

\section{b) Modul Paralel}

Pemasangan modul juga dapat dipasang secara pararel, ini tergantung kebutuhan arus pada tegangan sistem. Pemasangan modul dengan secara pararel akan menghasilkan arus yang lebih besar. Jumlah modul yang dipararelkan tegantung perencanaan. Dimana arus yang mengalir dari string adalah :

$\mathrm{I}=\mathrm{I}_{1}+\mathrm{I}_{2}+\mathrm{I}_{3}$ (Ampere)

\subsubsection{Keluaran Modul Surya}

Adapun untuk menentukan daya max keluaran dari modul surya adalah dengan persamaan berikut:

$P_{p p v}=V_{p v_{-} \text {max }} \times I_{p v_{-} \text {max }}$

Dan daya efektif dapat juga ditentukan dengan persamaan:

$P_{\text {output }}=V_{\text {output }} \times I_{\text {output }}$

$P_{p v}=P_{p p v} \cdot N_{p v}$

$P_{p p v}=\frac{P_{\text {String }}}{N_{\text {Seri }}}$

Untuk menentukan tegangan efektif string dan modul PV array :

$P_{\text {String }}=\frac{V_{p v}}{N_{\text {String }}}$

$V_{p v}=N_{p v s} \times V_{p p v}$

Sedangkan untuk menentukan arus efektif dari PV array adalah sebagai berikut :

$I_{\text {String }}=\frac{I_{p v}}{N_{\text {String }}}$

Keterangan :

$\mathrm{P}_{\mathrm{ppv}} \quad=$ Daya panel PV $($ Watt $)$

$\mathrm{P}_{\mathrm{pv}} \quad$ = Daya PV-system (Watt)

$\mathrm{P}_{\text {String }} \quad=$ Daya String PV (Watt)

$\mathrm{I}_{\text {String }} \quad=$ Arus String PV (Ampere)

$\mathrm{V}_{\mathrm{pv} \_ \text {max }} \quad=$ Tegangan panel PV (Volt)

$\mathrm{I}_{\mathrm{pv} \_ \text {max }}=$ Arus panel PV (Ampere)

$\mathrm{N}_{\mathrm{pvs}} \quad=$ Jumlah panel PV yang di hubung seri (unit)

\subsection{Baterai/Aki ${ }^{[2,3,4,5,6,7,8]}$}

Accu (baterai) merupakan salah satu alat yang dapat mengkonversikan energi listrik menjadi energi kimia, atau energi kimia menjadi energi listrik. Kemampuan untuk menyimpan energi listrik ke dalam bentuk energi kimia memungkinkan penggunaannya dapat diperluas dalam sistem kelistrikan. Meskipun baterai berguna dalam piranti yang bisa dibawa-bawa atau piranti berdaya rendah, akan tetapi mempunyai waktu operasi yang terbatas. Ada beberapa jenis baterai salah satunya adalah baterai fluidic.

Tabel 1. Data Karakteristik Baterai fluidic

\begin{tabular}{cccccc}
\hline Model & $\begin{array}{c}\text { Number } \\
\text { of } \\
\text { Modules }\end{array}$ & $\begin{array}{c}\text { Max } \\
\text { Site Load } \\
\text { (A) }\end{array}$ & $\begin{array}{c}\text { Max } \\
\text { Site } \\
\text { Power } \\
\text { (W) }\end{array}$ & $\begin{array}{c}\text { Max } \\
\text { Charging } \\
\text { Power } \\
\text { (W) }\end{array}$ & $\begin{array}{c}\text { Min } \\
\text { Charging } \\
\text { Power } \\
\text { (W) }\end{array}$ \\
\hline FE1500 & 3 & 28 & 1500 & 2800 & 700 \\
FE2000 & 4 & 38 & 2000 & 3800 & 700 \\
FE2500 & 5 & 48 & 2500 & 4700 & 700 \\
FE3000 & 6 & 58 & 3000 & 5600 & 700 \\
\hline
\end{tabular}

*sumber : All Content Contained Herein Is Confidential And Proprietary Information of Fluidic Energy. (C2014 Fluidic Inc.

Dalam memberikan energi pada akumulator perlu diperhatikan besarnya DOD (Depth Of Discharge). Untuk menentukan besarnya total kapasitas penyimpanan pada akumulator dapat ditentukan dengan persamaan berikut :

$$
\begin{aligned}
& C_{b a t}=\frac{P_{b a t}}{V_{b a t} \times N_{b a t}} \\
& C_{\text {Tbat }}=C_{b a t} \cdot N_{b a t}
\end{aligned}
$$

Sedangkan untuk menentukan besar daya baterai adalah dengan menggunakan persamaan:

$P_{b a t}=V_{b a t} \times C_{b a t} \times N_{b a t}$

Untuk menentukan lama waktu baterai melayani beban dalah dengan menggunakan persamaa:

$T_{\text {Dbat }}=\frac{C_{\text {Tbat }} \times D O D \%}{I_{\text {load }}}$

Dan untuk mendapatkan lama waktu pengisian baterai adalah dengan menggunakan persamaa:

$T_{c h \_b a t}=\frac{C_{\text {Tbat }}}{I_{c h \_b a t}}$

Keterangan :

$\mathrm{P}_{\text {bat }}=$ Daya Baterai (Watt)

$\mathrm{C}_{\text {bat }} \quad=$ Kapasitas Baterai (Ah)

$\mathrm{C}_{\text {Tbat }}=$ Kapasitas Total Baterai (Ah)

$\mathrm{V}_{\text {bat }}=$ Tegangan baterai (Volt)

$\mathrm{N}_{\text {bat }} \quad=$ Jumlah Baterai sistem

$\mathrm{T}_{\text {Dbat }}=$ Waktu Dischage Baterai (hours)

$\mathrm{I}_{\text {ch_bat }}=$ Arus Charging Baterai (Ampera)

$\mathrm{T}_{\text {ch_bat }}=$ Waktu Chaging Baterai (hours)

DOD $=$ Depth Of Discharge $=80 \%$ 


\subsection{Charge Controller ${ }^{[2,4,6,7,8,9,11]}$}

Fungsi dasar dari charge controller adalah mengoperasikan baterai dalam batas-batas pengoperasian yang diberikan pabrik dengan memperhatikan kelebihan beban. Lagi pula charge controller dapat melakukan pengaturan secara otomatis untuk mencegah pengisian baterai yang berlebihan, digunakan sebuah kontrol pengisian untuk mendeteksi saat baterai terisi penuh dan untuk menghentikan atau mengurangi jumlah energi yang mengalir dari sumber energi ke baterai. Menghindari arus puncak dari $P V$-System sehingga besar kapasitas chager controller $125 \%$ dari arus daya PV-system. Menentukan kapasitas charge controller adalah sebagai berikut :

$I_{k c c}=I_{p v} \times 125 \%$

Keterangan :

$\mathrm{I}_{\mathrm{kcc}} \quad=$ Arus Kapasitas Charge Controler (Ampere)

$\mathrm{I}_{\mathrm{pv}} \quad=$ Arus Daya PV-system (Ampere)

\subsection{Data BTS Operator H3I}

\subsubsection{Data Beban BTS}

Data beban listrik BTS diperoleh dari data preventive maintenance (PM) yang dilakukan oleh pihak Operator H3I yang dilakukan setiap 6 bulan dengan cara mencatat hasil pengukuran dengan menggunakan alat ukur tang ampere/ampere meter dan volt meter, hasil pengukuran dapat dilihat pada tabel 2 dan tabel 3 .

Tabel 2. Data Pengukuran di Site 140392_Teluk Pasir

\begin{tabular}{cccccccc}
\hline & \multicolumn{6}{c}{ Load Power AC 3Ø } & \multicolumn{2}{c}{ Load Power DC } & \multicolumn{2}{c}{$\begin{array}{c}\text { Power DC Charging } \\
\text { Battery }\end{array}$} \\
\hline Phase & $\begin{array}{c}\text { Tegangan } \\
\text { AC } \\
\text { (Volt) }\end{array}$ & Phase & $\begin{array}{c}\text { Arus AC } \\
\text { (Ampere) }\end{array}$ & $\begin{array}{c}\text { Tegangan } \\
\text { DC } \\
\text { (Volt) }\end{array}$ & $\begin{array}{c}\text { Arus AC } \\
\text { (Ampere) }\end{array}$ & $\begin{array}{c}\text { Tegangan } \\
\text { DC (Volt) }\end{array}$ & $\begin{array}{c}\text { Arus AC } \\
\text { (Ampere) }\end{array}$ \\
\hline R-S & 378 & R & 5.24 & 54.5 & 32.21 & 54.5 & 32.21 \\
S-T & 380 & S & 5.53 & & & & \\
T-R & 381 & T & 5.83 & & & & \\
R-N & 219 & N & 0.69 & & & & \\
S-N & 219 & & & & & & \\
T-N & 220 & & & & & & \\
N-G & 2.2 & & & & & & \\
\hline
\end{tabular}

Tabel 3. Data Konsumsi daya pada BTS site 140392_Teluk Pasir

\begin{tabular}{ccc}
\hline $\begin{array}{c}\text { Daya AC 3Ø } \\
(\mathrm{KW})\end{array}$ & $\begin{array}{c}\text { Daya DC } \\
(\mathrm{KW})\end{array}$ & $\begin{array}{c}\text { Daya DC } \\
\text { Charging Battery } \\
(\mathrm{KW})\end{array}$ \\
\hline 2,92 & 1,8 & 0,64 \\
\hline
\end{tabular}

\section{Desain Teknis dan Analisis}

\subsection{Prototipe Pengendali}

Pada sistem kendali ini dirancang untuk dapat mengkombinasikan sumber listrik dari PLN dan Photovoltaic system (PV-system) sehingga dapat mempercepat dalam melakukan pengisian baterai. Rancangan untuk simulasi prototipe pengendali tersebut menggunakan sistem pengaturan dengan kendali switch dan menggunakan daya rendah (tegangan 12 Volt dan arus 5 Ampere). Adapun sistem kerja kendali ini yaitu sebagai berikut : a) Pada kondisi suplai PLN off / tegangan rendah (< 200 VAC), maka beban akan disuplai oleh PV dan baterai, selama kondisi baterai masih dalam kondisi $>30 \%$.

b) Pada kondisi baterai sudah kosong sampai level yang disyaratkan maka PLN dan PV-system mulai beroperasi untuk mensuplai pengisian baterai mencapai 80-100\% kapasitasnya (tergantung seting parameter). Pada kondisi ini kendali bekerja sebagai charger dan mensinkronkan antara sumber energi dari PLN (keluaran tegangan DC dari power supply) dan PVsystem (keluaran tegangan DC) untuk melakukan percepatan dalam pengisian baterai dan mempersingkat waktu pengisian.

c) Pada kondisi suplai PLN off / tegangan rendah $(<200$ VAC) dan baterai sudah kosong sampai level yang disyaratkan maka PV-system tetap beroperasi untuk mensuplai pengisian baterai mencapai $70-80 \%$ kapasitasnya (tergantung pengaturan parameter).

Dari sistem kerja kendali kombinasi sumber PLN dan energi surya di atas dapat digambarkan dalam diagram state dan diagram block seperti pada gambar 2 dan gambar 3:

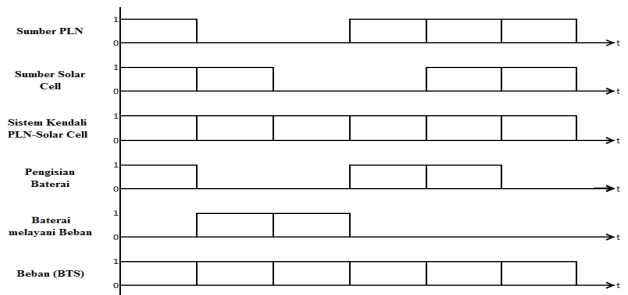

Gambar 2. Diagram State Rancangan Simulasi Prototipe Pengendali PLN dan $P V$-system

Keterangan :

1 = Kondisi "On"

$0=$ Kondisi "Off"

$\mathrm{t}=$ waktu

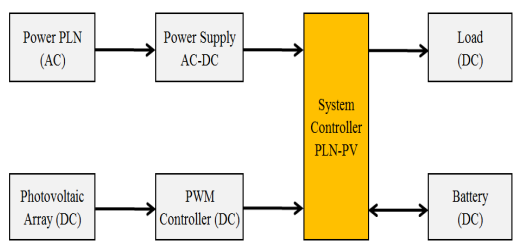

Gambar 3. Diagram Block Rancangan Simulasi Prototipe Pengendali PLN dan $P V$-system

Berdasarkan sistem kerja kendali dan diagram block kendali dapat dilakukan perancangan rangkaian kendali, bisa dilihat pada gambar 4 :

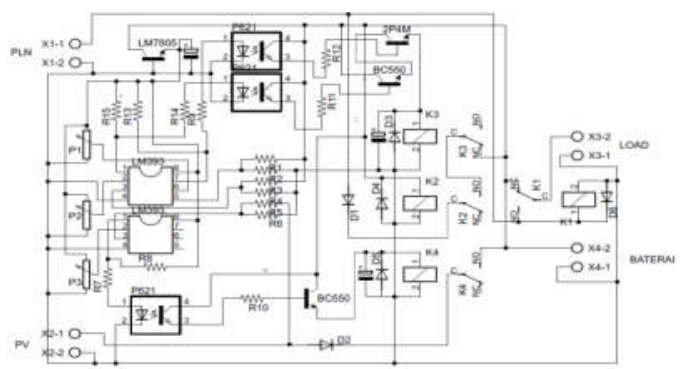

Gambar 4. Skematik Rancangan Simulasi Prototipe Pengendali PLN dan $P V$-system 


\subsection{Data Hasil Pengamatan Simulasi Prototipe}

Data didapatkan dari hasil simulasi pengukuran pada output kendali yang menggabungkan sumber listrik dari PLN dan PV-system. Hasil simulasi dapat dilihat pada gambar berikut ini:

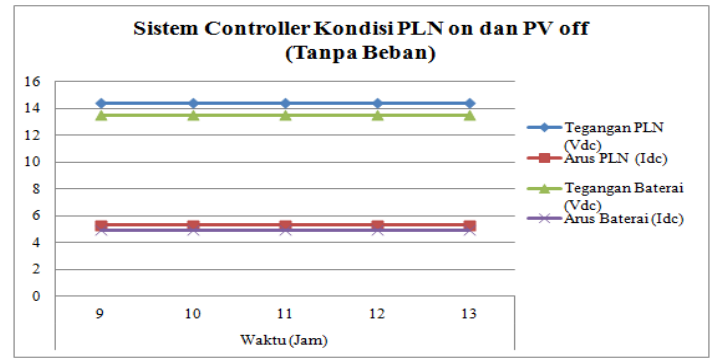

Gambar 5. Grafik Sistem Kendali Kondisi PLN on dan PV off (Tanpa Beban)

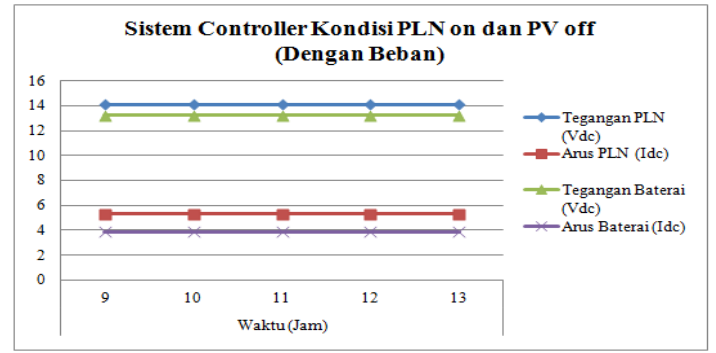

Gambar 6. Grafik Sistem Kendali Kondisi PLN on dan PV off (Dengan Beban)

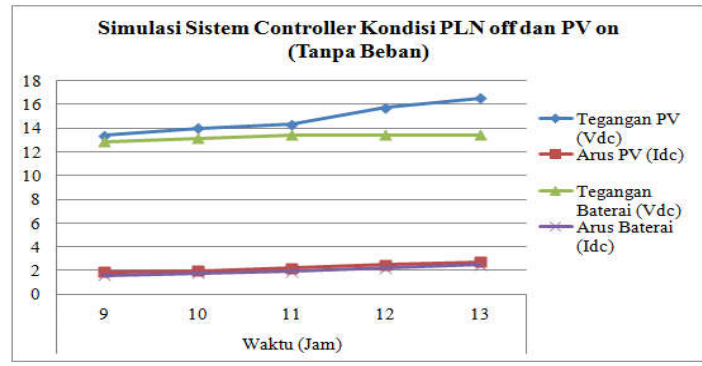

Gambar 7. Grafik Sistem Kendali Kondisi PLN off dan PV on (Tanpa Beban)

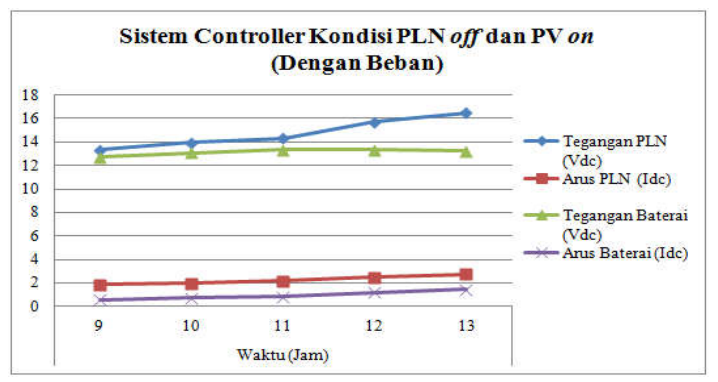

Gambar 8. Grafik Sistem Kendali Kondisi PLN off dan PV on (Dengan Beban)

Dari hasil pengukuran simulasi ini tegangan dan arus output dari rangkaian kendali didapat bahwa dengan menggabungkan kedua sumber energi tersebut bisa menaikkan arus untuk melakukan pengisian baterai. Dengan menambahkan beban tidak mempengaruhi sistem kerja kendali, ini menandakan bahwa sinkronisasi sistem kendali berjalan dengan baik.

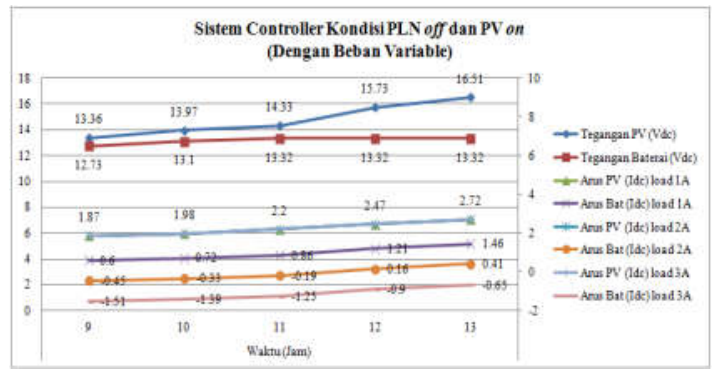

Gambar 9. Grafik Sistem Kendali Kondisi PLN off dan PV on (Dengan Beban Lampu 12V dan 1A ; 2A ; 3A)

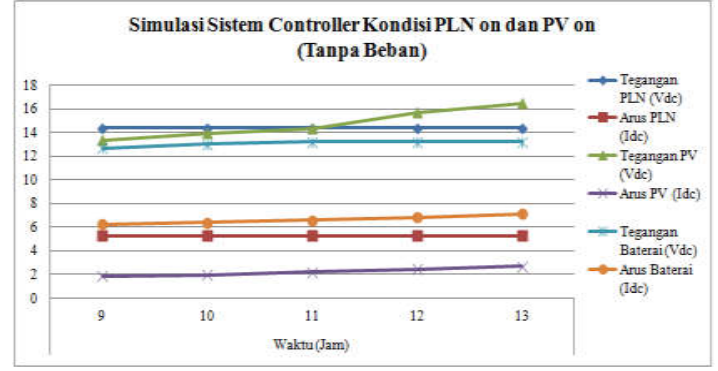

Gambar 10. Grafik Sistem Kendali Kondisi PLN on dan PV on (Tanpa Beban)

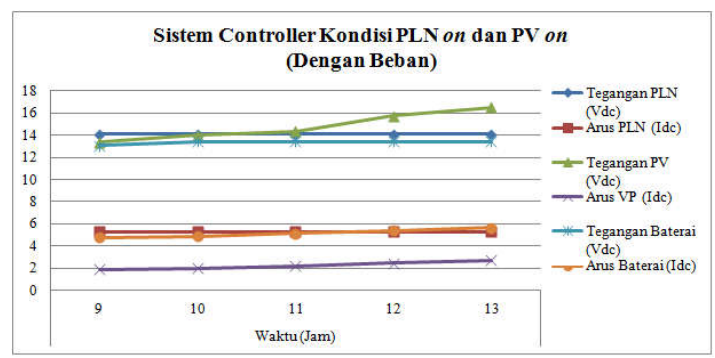

Gambar 11. Grafik Sistem Kendali Kondisi PLN on dan PV on (Dengan Beban)

\subsection{Perhitungan Rancangan Sistem}

\subsubsection{Perhitungan Jumlah PV}

Berdasarkan data pengamatan yang dilakukan pada BTS site 140392_Teluk Pasir, dapat dihitung jumlah panel PV yang dibutuhkan pada BTS sebagai berikut :

a) Perhitungan arus maksimum pengisian baterai.

Daya maksimum pengisian baterai sebesar 3800 watt dan jenis baterai Fluidic FE2000 dengan tegangan pengisian baterai 54,5 volt.

$$
\begin{aligned}
& P_{c h_{-} b a t_{-} \max }=V_{c h_{-} b a t} \times I_{c h_{-} b a t_{-} \max } \\
& I_{c h_{-} b a t_{-} \max }=\frac{P_{c h_{-} b a t_{-} \max }}{V_{c h_{-} \text {bat }}}
\end{aligned}
$$




$$
=\frac{3800 \mathrm{~W}}{54,5 \mathrm{~V}}=69,73 \mathrm{~A}
$$

b) Dari pengukuran arus pengisian baterai saat ini sebesar 11,18 A sehingga dapat dihitung besar arus yang dibutuhkan untuk rancangan PV-system yaitu:

$$
\begin{aligned}
I_{c h_{-} p v} & =I_{c h_{-} \text {bat_max }}-I_{c h_{-} \text {bat }} \\
& =69,73 \mathrm{~A}-11,18 \mathrm{~A}=58,55 \mathrm{~A}
\end{aligned}
$$

c) Perhitungan daya yang butuhkan untuk pengisian baterai adalah:

$$
\begin{aligned}
P_{c h_{-} p v} & =V_{c h_{-} b a t} \times I_{c h_{-} p v} \\
& =54,5 \mathrm{~V} \times 58,55 \mathrm{~A}=3190,98 \mathrm{~W} \approx 3,19 \mathrm{KW}
\end{aligned}
$$

PV-system akan melayani beban dari pukul 07:0017:00 maka perharinya PV-system hanya akan berkerja kira-kira 10 jam.

$$
\begin{aligned}
P_{p v / d a y} & =P_{c h-p v} \times 10 h \\
& =3,19 \mathrm{KW} \times 10 \mathrm{~h}=31,9 \mathrm{KWh} / \text { day }
\end{aligned}
$$

Adanya losses (rugi-rugi) dari internal baterai, kendali dan kabel dapat di asumsikan losses sebesar $20 \%$ maka daya PV perhari $=120 \% \times 31,9 K W h /$ day $=38,28 \mathrm{KWh} /$ day. Panel PV yang akan digunakan pada perancangan ini dengan kapasitas 200Wp permodul. Dengan mempertimbangkan kondisi intensitas cahaya matahari yang tidak sama sepanjang hari sehingga diasumsikan sekitar $100 \mathrm{Wp}$ maka daya per panel PV perhari adalah:

$$
\begin{aligned}
P_{p p v / d a y} & =C_{p p v} \times 10 \mathrm{~h} \\
& =100 \mathrm{Wp} \times 10 \mathrm{~h}=1000 \mathrm{Wh} \approx 1 \mathrm{KWh}
\end{aligned}
$$

d) Perhitungan untuk jumlah kebutuhan panel PV.

$$
\begin{aligned}
N_{p v s t r i n g} & =\frac{N_{p v}}{N_{p v s}} \\
& =\frac{39}{2}=19,5 \approx 20 \text { string }
\end{aligned}
$$

Dikarenakan oleh keterbatasan luas lokasi yang diijinkan untuk penambahan peralatan pada BTS site 140392_Teluk Pasir. Besarnya space yang diijinkan adalah $18 \mathrm{~m}^{2}$ (6 meter x 3 meter).

e) Perhitungan tegangan, arus dan daya PV-system dengan 12 unit panel PV yaitu:

$$
\begin{aligned}
V_{p v} & =N_{p v s} \times V_{p p v} \\
& =2 \times 26,9 \mathrm{~V}=53,8 \mathrm{~V} \\
I_{p v} & =N_{p v s t r i n g} \times I_{p p v} \\
& =6 \times 7,43 \mathrm{~A}=44,58 \mathrm{~A} \\
P_{p v} & =V_{p v} \times I_{p v} \\
& =53,8 \mathrm{~V} \times 44,58 \mathrm{~A}=2398,4 \mathrm{~W} \approx 2,4 \mathrm{KW}
\end{aligned}
$$

\subsubsection{Kapasitas Charger Kendali PV-system}

Untuk kapasitas charger kendali PV-system yang cocok untuk gunakan pada sistem ini adalah:

$$
\begin{aligned}
I_{k c c} & =I_{p v} \times 125 \% \\
& =44,58 \mathrm{~A} \times 125 \%=55,725 \mathrm{~A}
\end{aligned}
$$

\subsubsection{Waktu Discharging Baterai}

Diketahui bahwa baterai yang terpasang dilokasi BTS dengan kapasitas $16 \mathrm{KW}$ sehingga Waktu Discharging Baterai dapat dihitung sebagai berikut:

$$
\begin{aligned}
P_{b a t}= & V_{b a t} \times C_{b a t} \times N_{b a t} \\
C_{b a t} & =\frac{16 \mathrm{KW}}{48 \mathrm{~V} \times 2}=166,67 \mathrm{Ah} \\
T_{\text {Dbat }} & =\frac{C_{\text {Tbat }} \times D O D \%}{I_{\text {load }}} \\
& =\frac{333,34 \mathrm{Ah} \times 80 \%}{32,21 \mathrm{~A}}=8,28 \mathrm{~h} \approx 8 \mathrm{~h} 16 \text { menit }
\end{aligned}
$$

\subsubsection{Waktu Pengisian Baterai}

Waktu pengisian baterai dengan kombinasi sumber listrik PLN dan PV-system. Dengan mempertimbangkan kondisi intensitas cahaya matahari yang tidak sama sepanjang hari sehingga diasumsikan sekitar 50\%.

$$
\begin{gathered}
P_{p v}=2398,4 \mathrm{~W} \times 50 \%=1199,2 \mathrm{~W} \\
I_{c h_{-} p v}=\frac{P_{p v}}{V_{p v}}=\frac{1199,2 \mathrm{~W}}{53,8 \mathrm{~V}}=22,29 \mathrm{~A} \\
I_{c h_{-} p \ln p v}=I_{c h_{-} p \ln }+I_{c h_{-} p v} \\
=11,18 \mathrm{~A}+22,29 \mathrm{~A}=33,47 \mathrm{~A} \\
T_{c h_{-} \text {bat }}=\frac{C_{\text {Tbat }}}{I_{c h_{-} p \ln p v}}=\frac{333,34 \mathrm{Ah}}{33,47 \mathrm{~A}}=9,96 \approx 9 \mathrm{~h} 58 \text { menit }
\end{gathered}
$$

Dari hasil perhitungan waktu pengisian baterai dengan sistem satu sumber yaitu sumber dari PLN dibandingkan denga dua sumber yaitu sumber dari PLN dan PV-system, waktu yang dibutuhkan untuk pengisian baterai lebih cepat dengan waktu 9 jam 58 menit dan dapat menghemat waktu sebesar 14 jam 54 menit (29 jam 49 menit - 9 jam 58 menit $=19$ jam 51 menit).

\subsection{Design Perancangan Sistem Pada BTS 140392}

Pada BTS ini digunakan 12 unit panel PV (2 unit panel PV dihubungkan seri (1 string) dan 6 string PV dihubungkan parallel) dan dipasang di atas rack equipment BTS. design rancangan dengan 1 (satu) charger kendali akan melayani 3 (tiga) string PV dengan spesifikasi charging kendali adalah MPPT 12V/24V 20A sebanyak 2 unit dan output charger kendali dihubungkan secara seri supaya mendapatkan tegangan mendekati 54,5 V sehingga besar daya output PV-system sebesar 559,5 watt, maka waktu yang dibutuhkan untuk pengisian baterai hingga penuh selama 14 jam 56 menit. Design rancangan sistem pada BTS 140392_Teluk Pasir dapat dilihat pada gambar 12, 13 dan 14. 


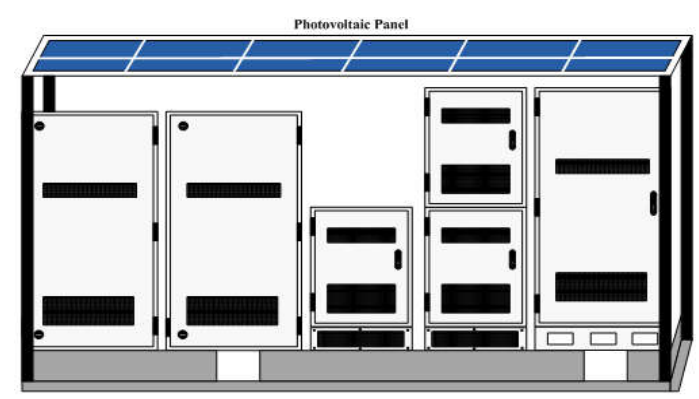

Gambar 12. Rancangan Posisi $P V$ di BTS 140392

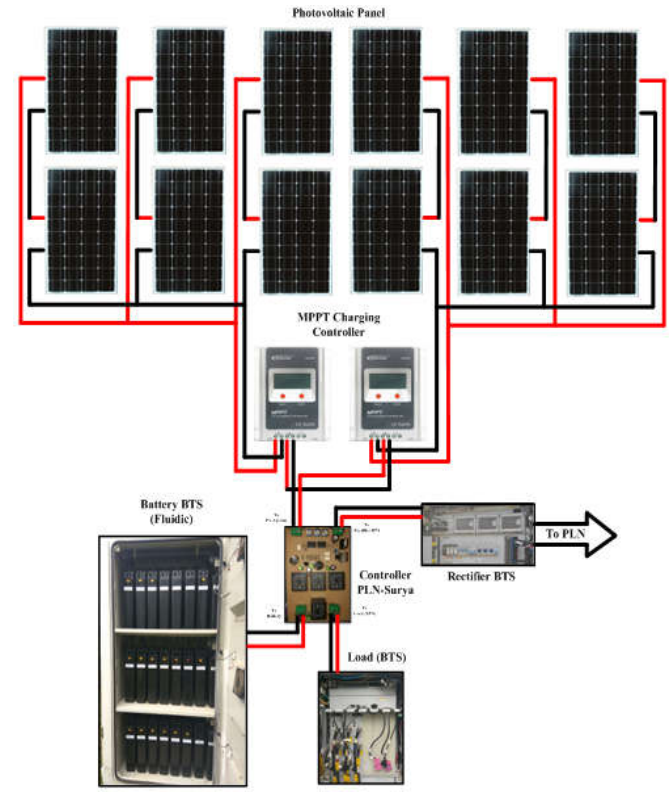

Gambar 13. Rancangan Wairing diagram Sistem Kombinasi Sumber Listrik PLN dan Energi Surya

\section{Kesimpulan}

1. Pengujian sistem kendali kombinasi sumber PLN dan energi surya dapat menggabungkan/ mensinkronkan output dari kedua sumber energi dengan menaikkan arus untuk supplai pengisian baterai sehingga waktu yang dibutuhkan pada pengisian baterai lebih cepat.

2. Pada kondisi maksimum daya dari kedua sumber, sistem kendali kombinasi sumber PLN dan energi surya mempunyai efisiensi sebesar $80 \%-90 \%$ ini disebabkan oleh adanya rugi-rugi daya pada kendali, PV-system dan kabel.

3. Dari perancangan sistem kombinasi sumber PLN dan energi Surya di BTS site 140392 Teluk Pasir membutuhkan waktu untuk pengisian baterai selama 14 jam 56 menit dan dapat mempersingkat waktu pengisian sebesar 14 jam 58 menit dari sistem yang saat ini digunakan sehingga sistem ini secara teknis layak untuk diterapkan di lapangan.

\section{Referensi}

[1] Abdul Kadir, 1995, Energi Sumber Daya Inovasi Tenaga Listrik dan Potensi Daerah, Universitas Indonesia Press, Jakarta.

[2] Noviani Rahmawati, dkk, Pembangkit Listrik Hibrid (Analisa Perbandingan Pada Pembangkit Listrik BTS), Magister Teknik Elektro Fakultas Teknik Universitas Indonesia, 2012.

[3] Malvino, Barmawi M.dan Tjia, M.O,1986. Prinsip-Prinsip Elektronika, PT. Erlangga, Jakarta.

[4] Tri Susanto, Studi Evaluasi Kinerja PLTH Surya-Genset Pada BTS (Base Transceiver Station) PT. Telkomsel di Kecamatan Lembah Bawang Kabupaten Bengkayang, Fakultas Teknik Elektro Universitas Tanjungpura Pontianak, 2014.

[5] Tarigan Drs, M.Eng Sc, Dasar Sistem Sel Fotovoltaik, LIPI, 1983.

[6] Hera Arwoko, 1997, Efisiensi Baterai Daya Dari Solar Sel, Unitas, Jakarta.

[7] Fitria Yulinda, Rancangan Bangun Simulasi Sistim Hybrid Tenaga Surya dan Tenaga Angin Sebagai Catu Daya Base Transceiver Station (BTS) 3G, Fakultas Teknik Program Teknik Elektro Depok, 2009.

[8] http://elektronika-dasar.web.id/artikel-elektronika/inverterdc-ke-ac/\#chitika_close_button.

[9] Yadi Muhammad, Analisis Peningkatan Kualitas Jaringan Telekomunikasi Melalui perangkat Base Transceiver Station (BTS) Flexi Multirandio (FMR) Pada Nokia Siemens Networks(NSN), Skripsi Fakultas Teknik Universitas Tanjungpura, Pontianak 2012.

[10] http://panelsurya.com. 2011, Sistem panel surya.

[11] Tim penyusun, Modul Teknik Dasar Rectfier dan Inverter, Fakultas Teknik Universitas Negeri Yogyakarta, 2003.

\section{Biography}

${ }^{1)}$ M. Ridhwan Sufandi, lahir di Pontianak pada tanggal 04 Februari 1986. Menyelesaikan pendidikan D-3 Teknik Elektro di Politeknik Negeri Pontianak Tahun 2007, pendidikan S-1 Teknik Elektro di Universitas Tanjungpura Pontianak Tahun 2012 dan S-2 Teknik Elektro di Universitas Tanjungpura Pontianak Tahun 2017. Sejak tahun 2013 sampai dengan sekarang bekerja sebagai RTS Kalimantan Barat di PT. Huawei Tech Invesment.

${ }^{2}$ Wiwit Indah Rahayu, lahir di Kubu Raya pada tanggal 29 Februari 1988. Lulus Sarjana Teknik Informatika Universitas Tanjungpura Tahun 2011 dan lulus Pasca Sarjana Teknik Elektro Universitas Tanjungpura Pontianak tahun 2017. Saat ini beraktifitas di AMIK BSI Pontianak 